Archived version from NCDOCKS Institutional Repository - http://libres.uncg.edu/ir/asu/

Abbott, L.T. and Abbott, J.P. (1986) National Transportation Week: Second Week in May.

Reference Services Review, 14(4): 37-44 (December 1986). Published by Emerald Group

Publishing (ISSN: 0090-7324). DOI: 10.1108/eb048960. The version of record is available from: www.emeraldinsight.com

\title{
National Transportation Week: Second Week in May
}

Lisa T. Abbott and John P. Abbott

\begin{abstract}
The topic of transportation incorporates a vast amount of divergent information. The subject matter varies greatly, and includes titles ranging from Camels of the Outback to The Great American Motion Sickness; or Why You Can't Get There from Here. To establish boundaries for this resource guide, the present authors referred to Public Law 87-449, 14 May 1962, which authorized the president to proclaim an annual National Transportation Week. Using this as a basis, they defined transportation As the movement of people or goods from one place to another, and included a little tourism to break up the concrete and steel. While some historical materials are included, this resource guide emphasizes modes of transportation currently used in the United States.
\end{abstract}




\title{
INTRODUCTION
}

The topic of transportation incorporates a vast amount of divergent information. The subject matter varies greatly, and includes titles ranging from Camels of the Outback to The Great American Motion Sickness; or Why You Can't Get There from Here. To establish boundaries for this resource guide, the present authors referred to Public Law 87-449, 14 May 1962, which authorized the president to proclaim an annual National Transportation Week. Using this as a basis, they defined transportation As the movement of people or goods from one place to another, and included a little tourism to break up the concrete and steel. While some historical materials are included, this resource guide emphasizes modes of transportation currently used in the United States.

The arrangement of the guide is by type of resource, rather than by mode of transportation. Materials are listed alphabetically within each section. The guide includes most types of materials, with the exception of journal articles and audio-visual media. It is not meant to be complete, but is designed to identify a cross-section materials that are likely to be available in medium-sized public and academic libraries. This resource guide includes the following sections: General; Abstract Journals, Bibliographies, Databases and Indexes; Career; Dictionaries, Directories, Encyclopedias, Guides, and Handbooks; Juvenile/Young Adult; Legal; Maps; Statistics; and Travel.

\section{GENERAL}

\author{
* 4.1 * \\ Bowersox, Donald J., Pat J. Calabrao and George \\ D. Wagenheim. Introduction to Transportation. \\ New York: MacMillan, 1981. \$14.95. 400p. \\ ISBN 002313030X.
}

This book provides a foundation for understanding the United States transportation system.

Topics covered include the scope and role of 
transportation, transportation environments, and management and administration.

\footnotetext{
* 4.2 *

Coyle, John J., Edward J. Bardi and Joseph L.

Caninato. Transportation. 2d ed. St. Paul, MN:

West, 1986. \$24.95. 518p. ISBN 0314931686.

This text discusses the role and significance of transportation, basic modes, theory and practice of rates, the government's role, managerial issues, and the changing environment of transportation. This work is well-organized, and most chapters include study questions, notes, suggested readings, and case studies.
}

\section{* 4.3 *}

Fontgalland, Bernard de. The World Railway System. London: Cambridge University Press, 1984. \$29.95. 209p. ISBN 0-5212-4541-9.

This book provides an analysis of the world's rail systems. The contents include: principles and parameters, technology, production, sales, management, and macrosystems. The author discusses international organizations involved in standardization and coordination of rail systems.

\section{* 4.4 *}

Harper, Donald Victor. Transportation in America: Users, Carriers, Government. 2d ed. Englewood Cliffs, NJ: Prentice-Hall, 1982. \$31.95. 645p. ISBN 0-1393-0297-2.

The author discusses the roles of three groups in the United States domestic freight and passenger transportation system. The groups are users of transportation services (shippers, receivers, and passengers), providers of transportation services (carriers), and the government (federal, state, and local). 
Lieb, Robert C. Transportation: The Domestic System.

3d ed. Reston, VA: Reston Publishing, 1985.

\$27.95. 486p. ISBN 0-8359-7823-0.

This volume provides an overview of the structure, regulation, and performance of domestic inter-city transportation. The discussion includes six parts: scope and function, modes of inter-city carriage, cost and demand, regulation and promotion, management problems and policy issues, and metropolitan transportation. A bibliography follows each section.

* 4.6 * Moody's Transportation Manual and News Reports. 1954-. A. \$490. Moody's Investors Service, 99 Church St., New York, NY 10007. ISSN 0545-025X (Manual), 0027-089X (Reports).

This annual publication contains financial and operating data for nine hundred North American companies in all areas of transportation. Weekly Transportation News Reports supplement the annual editions.

* 4.7 *

Schonknecht, Rolf et al. Ships and Shipping of

Tomorrow. Hounslow, England: MacGregor, 1983. \$30. 240p. ISBN 0-8703-3299-6.

This work discusses future systems of sea transport.

* 4.8 *

Wixom, Charles W. ARBA Pictorial History of Roadbuilding. Washington, DC: American Road Builders Association, 1975. \$15. 207p.

The book relates the history of roadbuilding through photographs from the nineteenth and twentieth centuries. Coverage extends from the Indian trails to plank roads to modern freeways. This is one of the most interesting books examined for this bibliography. 


\section{ABSTRACT JOURNALS, BIBLIOGRAPHIES, DATABASES, AND INDEXES}

* 4.9 *

Abstract Newsletter: Transportation. 197?-. W. $\$ 80$. U.S. Department of Commerce. National Technical Information Service, 5285 Port Royal Rd., Springfield, VA 22161. SuDoc no. C51.9/9:. ISSN 0163-1527.

This service includes abstracts of the National Technical Information Service's technical reports dealing with air, pipeline, surface and subsurface transportation, transportation safety, and global navigation systems.

* 4.10 *

Current Literature in Traffic and Transportation. 1960-1982. M. 1983-. Bi-M. \$15. Northwestern University, Transportation Library, 1936 Sheridan Rd., Evanston, IL 60201. ISSN 0011-3654.

This work provides a subject listing of books, reports, conference proceedings, journal articles, and dissertations on transportation compiled by the Transportation Library. The book's scope is international.

\section{* 4.11 *}

Highway Research Information Service (HRIS) Abstracts. 1968-. Q. \$63. National Research Council, Transportation Research Board, Highway Research Information Service, 2101 Constitution Ave. NW, Washington, DC 20418. ISSN 0017-6222.

This book is divided into two sections. Abstracts of journal articles, research reports, and conference proceedings papers are grouped by broad subject area in the first secion. In the second are author, corporate source, and subject indexes. The scope of the work is international. HRIS is one subfile in the TRIS online database (Dialog file 63) cited below. 
* 4.12 *

Information Sources in Transportation, Material

Management, and Physical Distribution: An Annotated

Bibliography and Guide. Comp. by Rob J.

Davis. Westport, CT: Greenwood, 1976. \$35.

715p. ISBN 0-8371-8379-0.

This is an annotated bibliography and guide to resource materials in the broad areas of transportation, materials management and physical distribution.

* 4.13 *

Rail Book Bibliography 1948-1972: A Comprehensive Guide to the Most Important Rail Books, Publications and Reports. Ed. by F.K. Hudson. Ocean, NJ: Specialty, 1972. \$7.50. 225p. ISBN 0913556017.

A subject index provides access to this bibliography. It is somewhat dated but still useful.

* 4.14 *

Sources of Information in Transportation. 3d ed. 9 vols. Monticello, IL: Vance Bibliographies, 1985. Public Administration Series, P-1599 - P-1607. ISSN 0193-970X.

Bibliographies covering topics such as air, shipping, rail, trucking, inland water, pipelines, and motor and urban transportation are contained in this series.

* 4.15 *

Transportation and the Elderly: A Selected Bibliography. Washington, DC: U.S. Department of Health, Education and Welfare. Administration on Aging. Service Center for Aging Information, 1981. 44p. SuDoc no. HE 23:3011:T68.

This is a bibliography of approximately 475 sources published between 1976 and 1980. It brings together literature prepared by individuals, private organizations, research institutions, and government agencies. 
* 4.16 *

Transportation Research Information System, (HRIS), Dialog Information Retrieval Service, file 63. Dates and updates vary. $\$ 48 / \mathrm{hr}+$ other charges. Transportation Research Board, 2101 Constitution Ave. NW, Washington, DC 20418.

The TRIS online database is "a composite file whose records are either abstracts of documents and data holdings, or resumes of research projects that are relevant to the planning, development, operation and performance of transportation systems and their components." [from Dialog Bluesheet no. 63.] TRIS includes air, highway, maritime, rail, and urban mass transit subfiles. Most subfiles date from the mid-1970s. The TRIS database contains approximately 175,000 records.

\section{CAREERS}

* 4.17 *

Exploring Transportation Occupations. Ed. by Lawrence

A. Walsh. New York: Gregg Division, McGraw-Hill, 1976. \$12.52. 152p. ISBN 0070710236.

This work highlights transportation careers, and provides activities to give the reader the feeling and experience of the occupation's actual work environment. The text is written for a juvenile/young adult audience.

* 4.18 *

Geil, John J. and B. Stephen Johnson. Energy and Transportation: Industry and Careers. Englewood Cliffs, NJ: Prentice-Hall, 1976. \$8.84. Modular Exploration of Technology Series. 120p. ISBN 0132773929.

The authors discuss the basic concepts and careers available in the energy and transportation industries. The material is written for the young adult. 
* 4.19 *

Stevens, Lawrence. Your Career in Travel and

Tourism. Wheaton, IL: Merton House, 1983. \$10.

144p. ISBN 0-916032-19-1.

This work gives the reader general advice on employment and job hunting. There are also specific discussions of employers and opportunities in various transportation-related industries, including aviation, automobile, rail, bus, ship, tour and travel, food service, and hotels. The book features a directory of trade and professional organizations.

\section{DICTIONARIES, DIRECTORIES, ENCYCLOPEDIAS, GUIDES, AND HANDBOOKS}

\section{* 4.20 *}

The Car and Locomotive Cyclopedia of American Practices. 5th ed. Ed. by Kenneth Ellsworth. Omaha, NE: Simmons-Boardman, 1984. \$69.95. 755p. ISBN 0911382011.

This work consists of "definitions, illustrations and descriptions of railroad cars and locomotives, their components for domestic and export service, and shop practices. Directory of car and locomotive repair facilities, and...an almanac."

\section{* 4.21 *}

Dictionary of Tourism. Ed. by Charles J. Metelka. Wheaton, IL: Merton House, 1981. \$9.95. 87p. ISBN 0-916032-10-8.

This dictionary contains definitions of contemporary tourism industry terms.

\section{* 4.22 *}

Directory of Transportation Libraries/Information Centers in North America. 4th ed. Compiled by Transportation Division, Special Library Association. Cincinnati: ATE Information Services, 1984. $175 p$.

The directory provides access to transportation collections via alphabetic, subject, personal, and geographic indexes. 
* 4.23 *

Encyclopedia of Aircraft. Ed. by Michael J.H. Taylor and John W.R. Taylor. New York: Putnam, 1978. \$20. 253p. ISBN 0-297-77526-X.

This work offers an A to Z treatment of historical and contemporary aircraft. Illustrations, technical tables of aircraft specifications, and a small glossary are also included.

* 4.24 *

Encyclopedia of Railways. Ed. by O.S. Nock. London: Octopus, 1977. 480p. ISBN 0706406044.

This work discusses the development of locomotives, famous trains, and the history of rail travel. Sections also cover train operation, rapid transit, station architecture and preservation, and biographies of railroad personalities. A railroad chronology and glossary enhance this nicely-illustrated volume.

* 4.25 * Encyclopedia of Ships and Seafaring. Ed. by Peter Kemp. New York: Crown, 1980. \$30. 256p. ISBN 0517537389.

This book consists of a survey of the myriad varieties of boats and ships worldwide, biographies of famous seafarers and naval designers, and a roster of outstanding ships. It includes extensive illustrations.

* 4.26 *

Fodor's Railways of the World. Ed. by Robert C.

Fisher. New York: D. McKay, 1977. \$12.95. 374p. ISBN 0-679-00186-7.

This work provides an overview of travel by rail. It covers North America, West Europe, East Europe, Middle East, and South and Southeast Asia, South Asia, the Pacific, Africa, and South America. Some information may be dated. 
* 4.27 *

Jane's All the World's Aircraft. 1909-. A. \$125.

Jane's, 238 City Rd., London. Ed: John W.R. Taylor.

ISSN 0075-3017.

This series provides illustrations, descriptions, and specifications of aircraft arranged by type (airplanes, drones, missiles, etc.), and by country of origin. Indexes are available by type, manufacturer, and model. The index covers the previous ten editions.

\section{* 4.28 *}

Jane's Encyclopedia of Aviation. Ed. by Michael J.H. Taylor. London: Jane's, 1980. I,078p. 5v. ISBN 0-7106-0710-5.

This chronology of aviation history includes a directory, the history and fleet of world airlines and a directory of world air forces, bases, personnel and equipment sizes. The indexing is thorough.

\section{* 4.29 *}

Jane's World Railways. 1950/51-. A. \$125. Jane's, 238 City Rd., London. Ed: Geoffrey Freeman Allen. ISSN 0075-3084.

This is a directory of the world's railway companies listed by country. It describes company narratives, officers, route lengths by gauge, equipment, and investments and finances. Additional directories contain rail equipment manufacturers, associations, agencies, and rapid transit systems.

* 4.30 *

Lloyd's Ports of the World. 1982-. A. \$140.

Lloyd's of London Press, Inc., 87 Terminal Dr., Plainview, NY 11803. ISBN 0-907432-92-1.

This annual publication contains port data for over three thousand ports. The arrangement is by nine geographical regions, by country, and then alphabetical by port location. Port information includes geographic coordinates, port authority, approach, pilotage, accommodations, provisions, water, ship repair, and Lloyd's agents. 
* 4.31 *

OAG Air Cargo Guide. 1971-. M. \$57. OAG

Inc., 2000 Clearwater Dr., Oak Brook, IL 60521.

Ed: Herbert H. Howe. ISSN 019I-I52X.

The guide provides domestic and international cargo flight schedules, restrictions, packaging, maximum weights, and a destinations directory.

* 4.32 *

Official Airline Guide: North American Edition. 1958-. Bi-W. \$155. OAG Inc., 2000 Clearwater

Dr., Oak Brook, IL 60521. ISSN 0191-1619.

The Official Airline Guide reports schedules of airlines operating within North America (including the United States, Mexico, and the Caribbean).

* 4.33 *

Official Airline Guide: Worldwide Edition. 1976-. M. \$161. OAG Inc., 2000 Clearwater Dr., Oak Brook,IL 60521. ISSN 0364-3875.

The worldwide edition covers schedules of flights to, from and within Central and South America, Greenland, and the Eastern Hemisphere (Europe, Asia, Africa, and Australia). It includes schedules from these areas to and from North America.

* 4.34 *

Official Railway Guide: North American Freight Service Edition. 1868-. Bi-M. \$74. National Railway Publication Co., 424 W. 33rd St., New York, NY 10001. ISSN 0190-6704.

This serial lists freight and piggy-back schedules of many carriers, as well as lists of the officials of railroad systems in the United States, Canada, and Mexico.

* 4.35 *

Official Railway Guide: North American Travel

Edition. 1868-. 8/yr. \$56. National Railway Publication Co., 424 W. 33rd St., New York, NY 10001. ISSN 0273-9658. 
This guide contains timetables for Amtrak and other passenger railroad lines in the United States, Canada, and Mexico. Some foreign bus, ferry, and train schedules are also included.

* 4.36 *

Ports Annual. 1917-. A. \$25. Anchor Press, 1434 St. Catherine St. W., Suite 204, Montreal, Quebec H3G 1R4, Canada. ISSN 0225-5448.

This annual publication covers all major United States ports facilities, activities, and multi-modal services. The connecting transportation and trade operations are also listed.

* 4.37 *

Railway Age's Comprehensive Railroad Dictionary. Ed. by Robert G. Lewis. Omaha, NE:

Simmons-Boardman, 1984. \$17.95. 160p. ISBN 0-911382003.

The dictionary provides a guide to terms used in the modern railroad industry. It does not include slang from the steam era unless the words are still in use.

* 4.38 *

The Rand McNally Encyclopedia of Transportation. Chicago: Rand McNally, 1976. \$16.95. 256p. ISBN 0-528-81050-2.

This single volume illustrated encyclopedia covers land, sea, and air transportation, transportation milestones, and related topics such as fuels, personalities, and navigation.

* 4.39 *

Transportation Officials and Engineers Directory. A. \$7. American Road and Transportation Builders' Assn., 525 School St. SW, Washington, DC 20024.

This directory lists federal, state, and local road and transportation building agencies and personnel. 
* 4.40 *

World Aviation Directory. 1940-. S-A. \$75.

Ziff-Davis Publ. Co., 1156 15th St. NW, Washington,

DC 20005. ISSN 0043-826X.

This directory covers domestic and international air carriers, including officers, equipment, and basic financial information. It also lists airports, heliports, equipment manufacturers and suppliers, aviation repair facilities, and civil and military aviation agencies.

\section{JUVENILE/YOUNG ADULT}

\section{* 4.41 *}

Charlie Brown's Third Super Book of Questions and Answers: About All Kinds of Boats and Planes, Cars and Trains and Other Things That Move! Produced in Association with Charles M. Schultz Creative Associates. New York: Random House, 1978. \$9.95. 145p. ISBN 0-394-83729-0.

Charlie Brown and the Peanuts gang help present a host of facts about various modes of transportation in a question and answer format for students in grades four through seven.

* 4.42 *

The Complete Junior Encyclopedia of Transportation. Ed. by A.M. Zehavi. New York: Watts, 1973. \$8.95. 280p. ISBN 0531025969.

This is an encyclopedic treatment of transportation topics written and illustrated for a young reader.

* 4.43 * Coombs, Charles. Tankers: Giants of the Sea. New York: William Morrow, 1979. \$10. 127p. ISBN 0-688-22205-6.

The author discusses the use and construction of oil tankers, and describes the atmosphere on board. 
* 4.44 *

Encyclopedia of Aviation. New York: Charles

Scribner, 1977. \$14.95. 218p. ISBN 0-684-14840-4.

This encyclopedia contains specific information on civilian and military airplanes ranging from design and designers to technical concepts and terms. The volume is well-illustrated.

* $4.45^{*}$ Harris, Susan. Boats and Ships. New York:

Franklin Watts, 1979. \$8.60. 48p. ISBN 0531022706.

This book introduces readers in fourth through sixth grades to various types of ships and boats. The author highlights the text with historical facts.

* 4.46 *

Petersen, David. Helicopters. New True Book

Series. Chicago: Children's Press, 1983. \$10.60.

45p. ISBN 0516016806.

The author covers the history and operation of helicopters and includes a good glossary and an index. Other works in the series include: Airplanes, Airports, Cars, Ships and Seaports, and Trains.

* $4.47^{*}$

Reit, Seymour. Sails, Rails and Wings. New York:

Golden Press, 1978. \$4.95. 69p. ISBN 0307168042.

The work provides a look at historical and current transportation methods.

* 4.48 *

Roberts, David. The Great Book of Railways.

Windermere, FL: Ray Rourke, 1981. 45p. ISBN

0-86592-063-X.

This book highlights the 150-year history of railroads and describes modern railways, monorails, electric trains, and underground systems. 
* 4.49 *

Ships and Docks. Ed. by Donald Clarke. New

York: Arco, 1978. \$9.95. 120p. ISBN 0668045566.

Ships and Docks covers water transporters from merchant ships to whaling vessels. The book also discusses boatbuilding, propulsion, navigation, safety, salvage, and engineering. It contains numerous illustrations and photographs.

* 4.50 *

Transport through the Ages. Ed. by Peter Bray. New York: Taplinger, 1971. \$6.95. 128p. ISBN 0-8008-7832-9.

This volume traces transportation from rope bridges to space travel using an encyclopedic format. Four hundred line drawings illustrate the concepts.

* 4.51 * Unstead, R.J. See Inside an Airport. New York: Warwick, 1978. 28p. ISBN 0-531-09065-5.

The author describes various features of airports, including the control tower, operations room, boarding, and customs.

\section{LEGAL}

* 4.52 *

Fair, Marvin and John Guandolo. Transportation Regulation. 9th ed. Dubuque, IA: Wm. C. Brown, 1983. 500p. ISBN 0-697-08515-0.

This thorough work examines the regulation of carriers and transportation. It discusses the nature and administration of regulations in three sections: "Framework of Regulation," "Regulatory Policy," and "Practice, Procedure and Court Review."

* 4.53 *

Guandolo, John. Transportation Law. 4th ed. Dubuque, IA: Wm. C. Brown, 1983. I,072p. ISBN 0-697-08516-3. 
This volume provides an exposition of the laws and court cases affecting the transportation industry.

* 4.54 *

"Highways." Code of Federal Regulations Title

23, 1985 ed. Washington, DC: U.S. Government

Printing Office, 1985. SuDoc No. AE 2.106/3:23

1985.

* 4.55 *

"Transportation." Code of Federal Regulations Title 49, 1985 ed. Washington, DC: US GPO, 1985.

SuDoc No. AE 2.106/3:49 1985.

The Code of Federal Regulations is a codification of the general and permanent rules published in the Federal Register by the executive departments and the agencies of the federal government. This is a division of the code into fifty titles which represent broad areas subject to federal regulation. Title 23 covers highways and is in one volume. Title 49 covers transportation in nine volumes.

* 4.56 *

"Transportation." United States Code, Title 49, 1982 ed. Washington, DC: US GPO, 1983. SuDoc No. YI.2/5: 1982 v.18.

These are the laws of the United States concerning transportation.

\section{MAPS}

\section{* 4.57 *}

The National Atlas of the United States of America. Washington, DC: GPO, 1970. 417p. SuDoc No. I19.2:N21a.

A wonderful but somewhat dated resource that "was designed to be of practical use to decision makers in government and business, planners, research scholars, and others needing to visualize country-wide distributional patterns and relationships between environmental phenomena and human 
activities." [from the introduction]. A new edition is long overdue.

\section{* 4.58 *}

Rand McNally Commercial Atlas and Marketing Guide. 1876-. A. \$135. Rand McNally, Box 7600, Chicago, IL 60680. ISBN 0528200852.

This atlas is an essential reference source. It contains United States and Canadian road maps; interstate maps; a mileage and driving time map; a list of scheduled airlines servicing each state; a list of railroads serving the United States with miles of track, locations, and types of service; an Amtrak map with railroad distances; and population, economic, and statistical information for the United States, Canada, and other parts of the world.

\section{* 4.59 *}

Rand McNally Road Atlas. 1924-. A. S5.95.

Rand McNally, 8255 N. Central Park Ave. Skokie, IL 60676. Ed: John Manning. ISBN 0-528-89091-3.

This is an inexpensive atlas of highway road maps arranged by state. It also features city maps and less detailed maps of Mexico and Canada, and contains mileage tables and time-traveled maps.

* 4.60 *

Travel Centers of the World: 10,000 Map and

Travel Publications Reference Catalog. 7th ed.

Hollywood, CA: Travel Centers of the World, 1983.

\$19.95. 335p. ISBN 096116980X.

This volume provides a worldwide list of tourist guides, topographic maps, road maps, aeronautical maps, and historical maps that are available for purchase.

\section{STATISTICS}

\section{* 4.61 *}

Census of Transportation. 1963-. Quinquennial.

U.S. Department of Commerce, Bureau of the Census, 
Washington, DC. SuDoc no. C3.233/3:.

This document consists of four surveys.

The National Transportation Survey provides data on volume and characteristics of travel by United States citizens. The Truck Inventory and Use Survey collects data on the characteristics and operational use of the nation's privately-owned truck resources. The Commodity Transportation Survey provides statistics on the volume and characteristics of intercity commodity shipments originated by manufacturers.

Finally, the Nonregulated Motor Carriers and Public Warehouse Survey presents data on motor carriers of persons and property that are not subject to federal regulation.

\section{* 4.62 *}

Highway Statistics. 1945-. A. U.S. Department of Transportation, Federal Highway Administration, Washington, DC. SuDocs no. TD 2.23: (year). ISSN 0095-344X.

This annual report presents an analysis of statistics on motor fuel, motor vehicles, driver licensing, highway-user taxation, state highway finance, highway mileage, and more. There are annual cumulations.

\section{* 4.63 *}

National Transportation Statistics. 1977-. A. U.S. Department of Transportation, Research and Special Programs Administration, Washington, DC. SuDoc no. TD 10.9: (year). ISSN 0161-8628.

This annual provides a summary of transportation statistics from government and private sources. Reports include cost, inventory, and performance data describing the passenger and cargo operations of several transportation modes: air carrier, general aviation, auto, bus, truck, local transit, rail, water, and pipeline.

* 4.64 * National Travel Survey. 1979-. Q. with annual cumulations. \$65. U.S. Travel Data Center, 1899 L St. NW, Washington, DC 20036. ISSN 0737-2620. 
This survey presents statistical information and summaries on many factors related to travel, including mode and purpose of travel, characteristics of travel, and traveler. The annual cumulation contains a glossary.

\section{TRAVEL}

\section{* 4.65 *}

Ford's International Cruise Guide. 1970/71- . Q. \$32. Ford's Travel Guides, Woodland Hills, CA 91365. ISSN 0015-7066.

This guide gives information about luxury cruises sailing from the United States, the Caribbean, the Mediterranean, and Europe. Sailing dates, fares, and ports of call are listed.

\section{* 4.66 *}

Gay, Jeanne. Travel and Tourism Bibliography and Resource Handbook. 3 vols. Santa Cruz, CA: Travel and Tourism Press, 1981. \$50. I,328p. ISBN 0-935638-00-8.

This is an ambitious bibliography in two parts within three volumes. "Geographical Bibliography and Resources" contains travel and tourism citations by regions and countries of the world. This volume also includes less familiar countries such as Brunei and the Kingdom of Tonga. "Subject Bibliography and Resources" contains citations of materials on travel and tourism topics, including the hospitality industry, leisure activities, and transportation.

\section{* 4.67 *} Grimes, Paul. The New York Times Practical Traveler. New York: Times Books, 1985. \$10.95. 41 Ip. ISBN 0-8129-1152-0 pa.

Grimes offers practical tips for traveling in the United States and abroad. He includes information on the Eurail pass, renting "wrecks," discounts for older travelers, special diets, lost luggage, 
and sections on traveling in South America, Africa, China, and the Soviet bloc.

* 4.68 *

Hotel \& Motel Red Book: The Official American Hotel \& Motel Association Lodging Directory for the Business Traveler. 1886-. A. \$45. Hotel \& Hotel Red Book, PO Box 7006, Lafayette, CA 94549. Ed: Valerie A. Dow. ISSN 0073-3490.

This reference tool offers entries for over ten thousand hotels and motels listed alphabetically by state and city. Each entry includes rates, distance to airport, and on-premise facilities. State highway maps and sixty city maps show hotel locations. A meeting planner's guide lists meeting room sizes and audio-visual equipment availability.

* 4.69 *

Hotel \& Travel Index. 1939-. Q. \$60. Hotel \&

Travel Index, PO Box 5820, Cherry Hill, NJ 08034.

Ed: Jerry Preece. ISSN 0162-9972.

This quarterly publication lists worldwide information on thirty thousand hotels, resorts, motels, guest ranches, and lodges. It reports on the hotel size, rates, distance from city center, nearest air terminal, airlines, and car rental agents. Entries are arranged in eight geographical regions.

* 4.70 *

Massow, Rosalind. Travel Easy: The Practical Guide for People Over 50. Washington, DC: Scott Foresman, 1985. \$8.95. 272p. ISBN 0-673-24817-8 pa.

Massow discusses issues of interest to the mature traveler, including the question of whether to travel alone or with others, air versus surface travel, medical concerns, and whether to travel in the United States or abroad. The book includes three appendixes: 1) state and national tourist offices, 2 ) reading list, and 3) maps of key tourist sites. 


\section{NOTE}

Country-by-country travel book series, such as Fielding's Travel Books, Fodor's Modern Guides and Ford's Travel Guides, contain useful tourist information on most countries in North, South and Central America, Europe, Asia, Africa, and Australia, and the Pacific. The titles are too numerous to list, but all contain advice and recommendations about travel, accommodations, food, shopping, and local customs. 